\title{
School-University Partnerships: A Model for Supporting Transition and Persistence from K-16
}

\author{
Catharine Dishke Hondzel, John Churchley, Susan Lidster
}

The reasons why students persist in their post-secondary learning are complex. This paper proposes a model for the development of K-16 partnerships that promote student success through the transition from secondary school to post-secondary, supported by teachers, faculty members, and educational developers. This model proposes that each of the partners engage in developing sustainable, collaborative projects. These projects have at their core a focus on students' transition from one educational institution to the next, with the intended outcome of increasing rates of persistence, while reducing rates of attrition. Not all students may have post-secondary education as their personal goal, but for those that do, this support model aims to provide a framework to scaffold the transition so that learners are successful, and teachers and faculty are prepared to support learners as they move from one institution to another.

Les raisons qui expliquent pourquoi les étudiants persistent dans leur apprentissage postsecondaire sont complexes. Le présent article propose un modèle pour l'élaboration de partenariats K-16 qui vise à favoriser la réussite étudiante lors de la transition de l'école secondaire à l'éducation postsecondaire avec l'appui d'enseignants, de professeurs et de concepteurs pédagogiques. À la base, ces projets se focalisent sur la transition des étudiants d'un établissement d'éducation vers un autre. Ils visent à faire augmenter le taux de persistance et à faire diminuer le taux d'abandon. L'éducation postsecondaire ne constitue pas forcément un but personnel pour tous les étudiants, mais pour ceux dont c'est l'objectif, le présent modèle vise à fournir un cadre pour structurer la transition et soutenir la réussite des apprenants de même que la préparation des enseignants et des professeurs qui appuieront les étudiants dans leur transition.

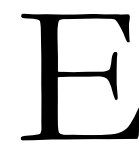

ach year thousands of high school students move into universities and colleges across Canada. Statistics Canada (2018) reports that over two million full, part-time, and continuing education students were enrolled in Canadian universities and colleges in the 2015/2016 academic year; 488,118 of whom are under the age of 20 . As such, Canada is well-positioned in the development of its human capital and, compared to other nations in the Organization for Economic Co-operation and Development (OECD), post-secondary participation is considered strong (Berger, 2009). However, student retention and persistence are an ongoing concern. Unfortunately, up to $40 \%$ of students do not persist into their second year (Childs, Finnie \& Martinello, 2017). Moreover, despite rising enrolment and registrations in universities and 
colleges, $30-43 \%$ of $18-24$-year-olds choose not to attend post-secondary at all (Berger, 2009).

There are many reasons why students choose to discontinue their studies. While it may be the appropriate course of action for certain individuals, high-school dropout rates suggest that the education system is not meeting the needs of its students which signals the poor use of resources (OECD, 2008; Parkin \& Baldwin, 2009). Widespread evidence suggests that student retention increases if and when institutions and instructors provide appropriate supports before and during the first years of study (Braxton \& McClendon, 2001, Braxton \& Mudy, 2001; Eitzen, Kinney \& Grillo, 2016; Lizzio \& Wilson, 2013; Pascarella \& Terenzini, 1991; Wilson et al. 2016).

The reasons why students are attracted to postsecondary education (PSE) and why students persist has been well-studied in the US, UK, and Canada. However, the specific factors that promote attraction and retention are not broadly generalizable across institutions and vary by institutional type, setting, and student characteristics (Caison, 2007). Economic and social factors are known to play an important role, and data shows that low-income students, firstgeneration students, and Indigenous students are consistently under-represented in post-secondary education (PSE) in Canada (Canadian Council on Learning, 2009). Further, motivational factors are critical, as students who see themselves as likely to be successful, are aware of viable career options, and who have meaningful social and financial support through the transition are more likely to seek out additional education.

Just as recruitment is key to ensuring a steady supply of students into PSE, serious attention must also be paid to retaining students and helping them be successful both academically and professionally (Albert, 2010; Chrysikos, Ahmed \& Ward, 2017). Retention is related closely to the concept of academic persistence, defined by Parkin and Baldwin (2009) as "the ability of students to continue their postsecondary studies from one year to the next and ultimately to proceed to the completion of the program" (p.65). Low levels of persistence may signal to institutions that financial resources are not being properly allocated. For open-access or regional institutions this may also mean the needs of the community remain unmet, thus the quality of life and overall prosperity may decrease (Parkin \& Baldwin, 2009). Whether or not a student persists is related to a variety of factors, many of which are wellresearched, and institutionalized as part of a system or program of student support and development. Tinto's (1993) widely employed model of student integration details the specific reasons why students leave PSE and has generated a variety of applications and approaches to support student persistence and reduce attrition.

Like many smaller post-secondary institutions in Canada, Thompson Rivers University (TRU) faces increasing pressure related to domestic enrolment and student retention and persistence. As a primarily undergraduate regional university with a significant open-access component, it is expected that we respond to the needs of the local population and build programs and opportunities that meet the needs of local learners. The model we propose in this paper aims to build sustainable partnerships that meet the needs of our region, but also serves as a model that we believe is replicable in other contexts and types of institutions.

\section{Literature Review}

It is outside the scope of this paper to provide extensive detail on all of the programs designed to support student persistence and reduce attrition; however, we have included an overview of the research in the field. Researchers regularly identify either pre-existing student factors or specific programs related to systematic improvement of student retention. Common factors include date of admission, program choice, academic preparedness, 
and student engagement (Fisher \& Engemann 2009). Others who focus on specific institutional policies and programs have referred to nine so-called policy levers (Braxton \& McClendon, 2001, Braxton \& Mudy, 2001; Pascarella \& Terenzini, 1991) that improve student retention. These nine constructs include a range of policy-enabled supports and services ranging from recruitment messages to academic advising, to classroom practices such as active and collaborative learning strategies. Much has also been made of the widespread implementation of high impact practices (Kuh, 2008; Johnson 2010), and the importance of fostering a sense of belonging in students (Rayle \& Chung, 2007).

The literature highlights a multitude of unique factors that contribute to students' choice to leave or persist in a program. Post-secondary institutions are complex organizations, striving to evolve in order to meet the needs of their communities. Members of these communities-students, faculty members, staff, and administrators-create programs emboldened (or hindered) by available resources, government funding, external accreditation requirements, and practitioner knowledge. These programs, systems, and approaches are neither implemented uniformly nor valued equally, thus making it impossible to compare institutions.

Though over-arching programs are difficult to compare, one common factor in the retention and persistence literature is that student engagement is positively correlated with student-faculty and peerto-peer connections (Braxton \& McClendon, 2001, Braxton \& Mudy, 2001; Kuh, 2008; Pascarella \& Terenzini, 1991; Rayle \& Chung, 2007; Tinto, 1993). Controlling for economic and social factors, students who interact with peers, engage with learning material, and feel they belong are more likely to persist. These students find value in the postsecondary community environment. When students feel they belong and are connected with others, they stay. This factor forms the foundation of the K-16 partnerships model. With a targeted focus on easing the transition between high school and university, students can develop a sense of belonging and community when they arrive on campus, feel understood, and supported as they navigate their way through post-secondary education.

Though not well-addressed in the student success and persistence literature, K-12 teachers and postsecondary faculty members can play a significant role in easing the transition into PSE and supporting student success and persistence (Rodriguez, et al. 2017). We refer to these as K-16 partnerships. This label is not meant to exclude students who take more than four years to graduate, mature students, or suggest that there are not significant pedagogical differences between each system of education. For those that include graduate school or postbaccalaureate study, the denotation K-20 may be more appropriate (Clifford \& Millar, 2008). There are also opportunities to include Pre-K education within these partnerships. K-16 partnerships are a critical first step in helping faculty members and teachers develop a deeper understanding of the issues, challenges, and changes in secondary education, while providing a platform for faculty members to describe and clarify the expectations required for students at the post-secondary level (Rodriguez et al., 2017). Dialogue between faculty members and teachers can build bridges thereby helping students feel prepared and well-supported, and provide a platform for collaboration in order to solve complex social problems (Briggs, Clark \& Hall, 2012; Walsh \& Backe, 2013). This dialogue not only improves clarity between teachers and faculty members, it also helps secondary school students understand what to expect in PSE, and how to build upon what they learned in secondary school. When students have clear expectations, appropriate social and financial support, and feel respected, they will fare better academically (Briggs, Clark \& Hall, 2012; Swail, Redd \& Perna, 2003). Faculty members play an important role in helping students feel supported, and are often a first point of contact when a student begins to struggle. Teachers in the K-12 system are widely regarded as the front line in student success, offering support and guidance to students. Partnerships 
between teachers and faculty members can create linkages to support students' transitions and help one another better understand the knowledge, behaviours, and abilities of students at both levels. Meaningful support in the transition between high school and post-secondary is vital to the success of students, and foundational in the formation of learner identity (Briggs, Clark \& Hall, 2012; Tinto, 1993).

The research on K-16 partnerships lacks a definition of the word "partnership" and fails to detail the members within the partnership (Clifford \& Millar, 2008), making it difficult to understand the underlying mechanisms that K-12 and postsecondary institutions use to work together and the key stakeholders involved. Simultaneously, there are a wide variety of stated purposes and goals for the K16 partnerships. Some of these partnerships are focused on inputs, such as building relationships for student recruitment and transfer, communitybuilding for educator preparedness, athletic development, and/or knowledge sharing for marketing or communications (Clark, 1988). Process-oriented partnerships may be focused on increasing community diversity or leadership capacity (Dyson, 1999), or on governance structures and building trust between members (Clifford \& Millar, 2008). However, the bulk of the research on school-university partnerships is focused on the tangible outputs or outcomes that benefit postsecondary institutions or faculty members. These include, but are not limited to, topics such as increased research productivity (McLaughlin \& Black-Hawkins, 2007) or the effectiveness and nature of student teacher training and practicum placements (e.g., Burton \& Greher, 20078; Jones et al., 2016; Guillen \& Zeichner, 2018; Martin, Snow \& Torrez, 2011). Comparatively, few studies discuss the role of K-16 partnerships in fostering student success, learning, or increasing post-secondary retention and persistence (Dyson, 1999; Walsh \& Backe, 2013).

Another neglected aspect of the K-16 literature is the role of educational developers, or curriculum development staff in managing and negotiating the relationships between teachers and faculty members. "Educational developer" refers to an individual whose job involves supporting effective faculty member instruction, developing teacher practice, thinking and motivation, and developing learning environments (Gibbs, 2013). The educational developer indirectly supports the institution and the faculty members to create and improve institutional teaching and learning strategies (Gibbs, 2013; McDonald et al., 2016). In the K-12 system, teachers that work with their colleagues in these areas have roles such as Curriculum Coordinator, Helping Teacher, or Staff Developer (York-Barr \& Duke, 2004). While these roles vary by institution, the aim of an educational developer is to support faculty in improving pedagogy and the student experience. Given the nature of this role, it seems fitting to use the skills, resources, and networks of educational developers in both K-12 and PSE systems to foster and support K-16 partnerships.

Any successful collaborative project must result in gains for all parties, and the partnerships should be strongly supported and advanced by the senior leadership at both the school and post-secondary level (Druckman, Peterson \& Thrasher, 2002; Jones et al., 2016; Peel, Peel \& Baker, 2002). Developing a partnership between schools and universities is a slow process built on a foundation of trust, communication, shared resources, and a willingness to collaborate (Dyson, 1999; Jones et al., 2016). In research partnerships or teacher practica experiences, the university typically drives the partnership, relying on the school district to provide data or host teacher candidates. Benefits to the K-12 partner are less clear but do include the recruitment of graduating teacher candidates (Cooper \& Alvarado, 2006) and coconstruction and evaluation of curriculum, instruction, and/or leadership strategies (Walsh \& Backe, 2013). Other school-university partnerships, such as dual credit courses, may benefit some students yet have less effect on underserved or marginalized students (Taylor, 2015). 


\section{Context}

The faculty and staff at TRU are committed to helping students succeed and persist in their postsecondary studies. TRU is a regional, open-access, primarily undergraduate university with approximately 26,000 students split evenly across campus and distance programs (TRU, 2018a). One of the strategic mandates of the university is to increase student success, especially in the context of transitions between high schools and the university. Kamloops is a small city of 90,000 people (Statistics Canada, 2017) that maintains close partnerships within the region, including with the TRU and the School District No. 73 (Kamloops-Thompson [SD73]). Institutional data reports show that more than $85 \%$ of SD73 students entering university directly from grade 12 go to TRU. In addition, many of the university's faculty and staff have children who attend local schools, and TRU students complete practicum placements locally or regionally. Strong informal ties already exist between SD73 schools and TRU.

Since 2015, TRU has partnered with SD73 in varied ways to support student transition and progression. This partnership developed organically, starting with connections made through the introduction of a Secondary Science, Technology, Engineering, and Math (STEM) stream to the TRU Bachelor of Education program. This encouraged a number of pre-existing partnerships to formalize into a joint committee called Mind the Gap. The committee has organized a series of networking events connecting K-12 teachers with university instructors. Educational developers from both systems are included, as are those in senior leadership (deans, directors, etc.) along with representatives from the Superintendent's Office. The joint committee's efforts are documented through websites and information videos (TRU, 2018b). Networking events have led to additional partnerships, including research, sharing of resources and equipment, joint pedagogical activities, and collaborative development of resources.

\section{A Model for K-16 Partnerships}

We propose a model (shown in Figure 1, below) that supports K-16 partnerships through the development of mutually meaningful relationships between teachers and faculty members, leading to heightened understanding, awareness, and preparedness to assist students with their transition. Our model extends Tinto's longitudinal model of institutional departure (1993, p. 114), with insight from Ethingon's model of student persistence (1990, p.283) and the student lifecycle model (Lizzio \& Wilson, 2013). The model shown in Figure 1 depicts a means by which student success and persistence may be supported by fostering connections through a distributed leadership model (Harris, 2014) between teachers and faculty members, and supported by educational developers, the school district, and the post-secondary institution. Ethington's model (1990), and to a lesser extent Tinto's model (1993), emphasize the personal variables that students bring to their education, such as goals, socioeconomic status, and academic selfconcept. Tinto's model of institutional departure includes the role of the external community and the role the academic system plays in student decisionmaking. Our addition does not supplant the many pre-existing conditions students bring to their education (e.g., family status or institutional characteristics). Instead, it proposes that meaningful connections between teachers and faculty will further assist students in achieving their academic goals. This proposed sub-model fills a gap in the literature and is recommended for consideration in forthcoming models of student persistence and retention that recognize the impact of institutional experiences and variables. 


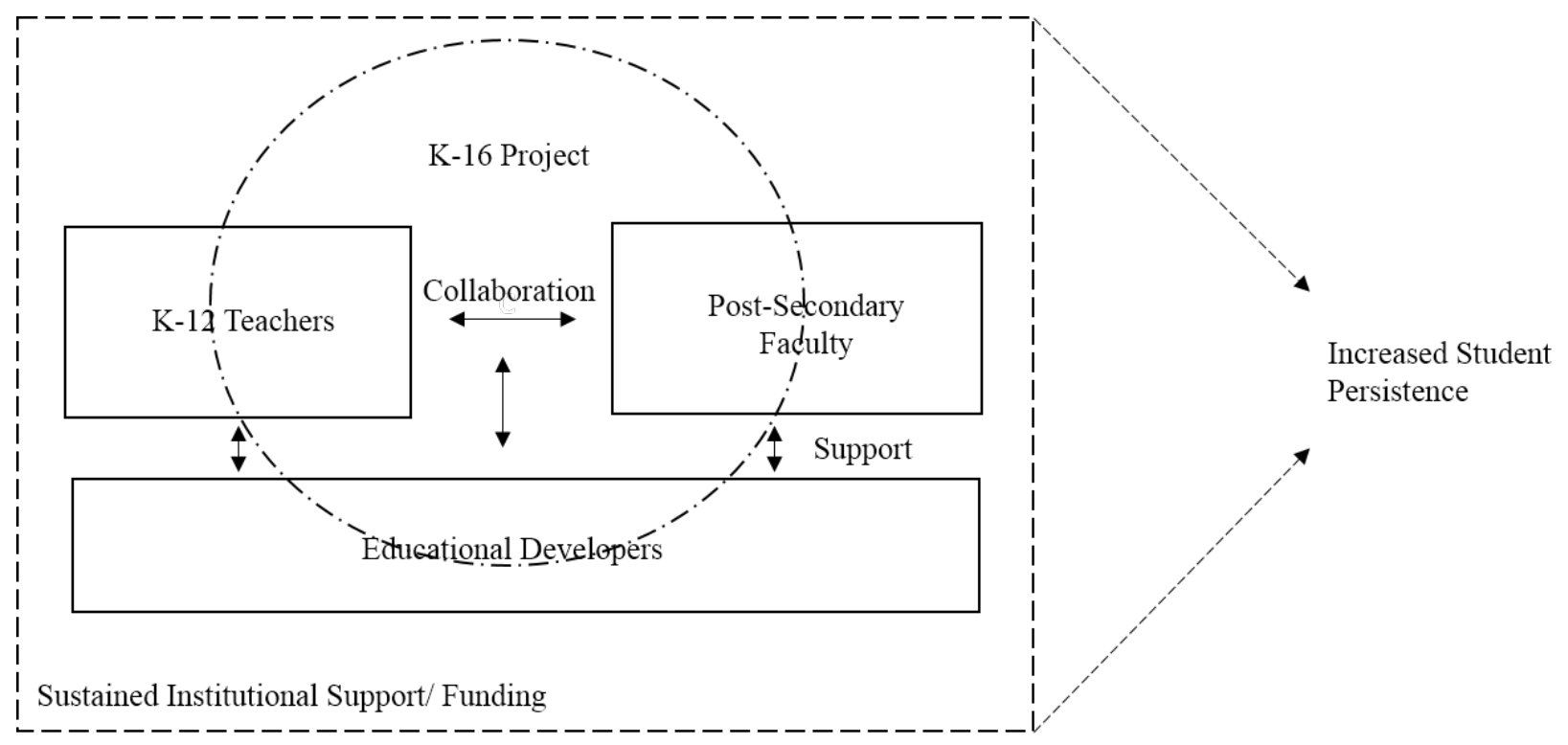

Figure 1. K-16 Partnership Model

We theorize that students who are in transition from high school to PSE will be better supported by secondary teachers (and by extension, elementary teachers) who understand the nature of the postsecondary environment and the expectations and roles of faculty members. Likewise, faculty members who are aware of the secondary curriculum and pedagogical practices may be better prepared to support student transitions. Transfer of knowledge occurs when these two parties interact and collaborate with each other in various ways to share information, resources, and co-develop research projects. This mutuality in partnership is recognized as a process of co-construction, trust, and shared understanding.

Educational developers at the secondary and postsecondary levels act as liaisons between teachers and faculty to support professional development, resource sharing, and structure conversations around learning outcomes at both levels. Using a distributed leadership approach (Harris, 2014) teachers and faculty members also work together to build partnerships to learn about each other's classroom. They expose students to the post-secondary environment, and gain awareness of the curriculum. In this process there are multiple leaders, each taking on different tasks over the period of the project.
Educational developers collaboratively provide administrative and budgetary support, while facilitating these connections and conversations through meetings, joint professional development initiatives and personalized encouragement and troubleshooting. In our project, the educational developer role belonged to a well-respected teacher who has previous experience in the school district, and who also serves as a faculty member in the Faculty of Education. This position (called a coordinator) was supported within the framework of the university's centre for teaching and learning, which provided program oversight and funding distribution as well as secretarial support. The educational developer was able to develop partnerships and make connections between faculty members and teachers thanks to an awareness of the roles and expectations in both institutional settings.

Schools and post-secondary institutions operate under confined budgets; therefore, additional funding is required to extend the conversations and create opportunities to establish sustainable partnerships. Partners must prepare a detailed proposal for operational infrastructure, including how funding will be obtained and how the partnership will be sustained (Walsh \& Backe, 2013). Small institutional grants to support projects are 
suggested as a means by which the post-secondary institution can encourage dialogue while enabling faculty members and teachers to develop mutually beneficial projects. Further, granting programs mitigate concerns over scarce resources and expanded or unrewarded responsibilities. We suggest that institutions establish grants for such things as teacher release from regular duties, travel, research assistance, materials, and other costs incurred over the course of the project term. In addition, the grant program signals an investment in project success by post-secondary administration, recognizing that these types of partnerships are often beyond the scope of faculty members' research, service, and teaching commitments. Grant holders should become part of a community of practice (Lave \& Wenger 1991) to support them in developing, sustaining, and reporting on their project. In addition, cohorts have proven to be a powerful means for building professional communities (Bullough \& Kauchak, 1997). We believe that this partnership model will develop and support meaningful relationships between faculty members and teachers, leading to increased student retention and academic success.

\section{Conclusion}

With the rapid change in $\mathrm{K}-12$ curriculum and the evolving needs of students as they move into postsecondary study, continuing dialogue and transparency is needed now more than ever. A key driver of our project was the implementation of a new BC secondary school curriculum. Campus-wide awareness of this provincial curricular change spurred strategic investment in line with the existing university strategic priorities (TRU, 2018c) to support student retention and success. In our model, university faculty members are supported to adapt their curriculum for students entering postsecondary with different skills than previously. Similarly, teachers are supported to learn how to effectively prepare their students for post-secondary studies. Fostering K-16 partnerships helps to meet these needs and could reduce student attrition, increase persistence, and build knowledge and understanding between teachers and faculty members.

By proposing this addition to other student retention and persistence models, we endeavour to highlight the important role that educational developers can play in academic partnership-building. Institutional change is often embraced reluctantly, and academic staff tend to view student attrition as connected to student deficit (Potter \& Bye, 2014). As stated earlier, teachers and faculty members are busy, with no shortage of tasks they are expected to accomplish. Building new bridges and partnerships may be seen as work with limited potential benefit. However, by making a modest investment in fostering K-16 partnerships and establishing a joint support unit to connect the two different education systems, it is possible to not only support student success, but measurably reduce student attrition during postsecondary study.

K-16 partnerships are built upon a mutuality of need and a capacity to respond, yet require the ability to navigate two different, complex systems. By investing in relationships, communication, and shared dialogue, both systems may develop the enhanced ability to direct program development efforts and respond with greater agility when major curriculum changes are implemented at the secondary level. The inclusion of this model in support systems directed at student persistence reinforces the need for planned and deliberate dialogue, as well as liaison between schools and postsecondary institutions. Together this enables informed decision-making and helps students succeed when they enter higher education. 


\section{References}

Albert, S. (2010). Student retention- A moving target. Council of Ontario Universities. Retrieved from https://cou.ca/wpcontent/uploads/2015/07/AcademicColleagues-Paper-Student-Retention.pdf

Briggs, A., Clark, J., \& Hall, I. (2012). Building bridges: Understanding student transition to university. Quality in Higher Education, 18, 3 21.

https://doi.org/10.1080/13538322.2011.61 4468

Berger, J. (2009). Participation in post-secondary education, recent trends. In J. Berger, A. Motte, \& A. Parkin. The price of knowledge: Access and Student Finance in Canada (4th Edition) (pp. 26-62). Montreal: Canada Millennium Scholarship Foundation.

Bullough, R. V., \& Kauchak, D. (1997). Partnerships Between Higher Education and Secondary Schools: Some problems. Journal of Education for Teaching, 23(3), 215-234. https://doi.org/10.1080/02607479719972

Braxton, J. M., \& McClendon, S. A. (2001). The Fostering of Social Integration and Retention through Institutional Practice. Journal of College Student Retention: Research, Theory \& Practice, 3(1), 57-71. https://doi.org/10.2190/RGXJ-U08C06VB-JK7D

Braxton, J. M., \& Mundy, M. E. (2001). Powerful Institutional Levers to Reduce College Student Departure. Journal of College Student Retention: Research, Theory \& Practice, 3(1), 91118. https://doi.org/10.2190/M127-V05B5E5J-F9LQ

Burton, S. L., \& Greher, G. R. (2007). SchoolUniversity Partnerships: What Do We Know and Why Do They Matter? Arts Education Policy Review, 109(1), 13-24. https://doi.org/10.3200/AEPR.109.1.1324
Canadian Council on Learning (2009). Post-secondary education in Canada: who is missing out?. Retrieved from https://www.tru.ca/__shared/assets/CCL _2009_Post_Secondary_Canada_Whos_Mi ssing_Out23674.pdf

Caison, A. (2007). Analysis of institutionally specific retention research: A Comparison Between Survey and Institutional Database Methods. Research in Higher Education, 48(4), 435-451.

Childs, S. E., Finnie, R., \& Martinello, F. (2017). Postsecondary Student Persistence and Pathways: Evidence From the YITS-A in Canada. Research in Higher Education, 58(3), 270-294. https://doi.org/10.1007/s11162016-9424-0

Chrysikos, A., Ahmed, E., \& Ward, R. (2017). Analysis of Tinto's student integration theory in first-year undergraduate computing students of a UK higher education institution. International Journal of Comparative Education and Development, 19(2/3), 97-121. https://doi.org/10.1108/IJCED-10-20160019

Clark, R. W. (1999). School-University Partnerships and Professional Development Schools. Peabody Journal of Education, 74(3/4), 164 177.

Clifford, M., \& Millar, S. B. (with Smith, Z., Hora, M., \& DeLima, L.). (2008). K-20 partnerships: Literature review and recommendations for research (WCER Working Paper No. 2008-3). Madison: University of WisconsinMadison, Wisconsin Center for Education Research. Retrieved from http://www.wcer.wisc.edu/publications/w orkingPapers/papers.php

Cooper, J. M., \& Alvarado, A. (2006). Preparation, recruitment and retention of teachers. IIEP education policy series No. 5. Paris and Brussels: The International Institute for Educational Planning and The International Academy of Education. 
Druckman, R., Peterson, L. M., \& Thrasher, M. S. (2002). Partnerships with K-12 education. New Directions for Higher Education, 2002(120), 11-18. https://doi.org/10.1002/he.84

Dyson, L. L. (1999). Developing a University-School District Partnership: Researcher-District Administrator Collaboration for a Special Education Initiative. Canadian Journal of Education / Revue Canadienne de l'éducation, 24(4), 411-425. https://doi.org/10.2307/1585895

Eitzen, A. M., Kinney, M. A., \& Grillo, K. J. (2016). Changing the Praxis of Retention in Higher Education: A Plan to TEACH All Learners. Change: The Magazine of Higher Learning, 48(6), 58-66. https://doi.org/10.1080/00091383.2016.12 47584

Ethington, C. (1990). A Psychological Model of Student Persistence. Research in Higher Education, 31(3), 279-293. Retrieved from http://www.jstor.org/stable/40195944

Fisher, R., \& Engemann, J. (2009). Factors affecting attrition at a Canadian college. Canadian Council on Learning. Retrieved from https://core.ac.uk/download/pdf/529759 67.pdf

Gibbs, G. (2013). Reflections on the changing nature of educational development. International Journal for Academic Development, 18(1), 4-14. https://doi.org/10.1080/1360144X.2013.7 51691

Guillen, L., \& Zeichner, K. (2018). A UniversityCommunity Partnership in Teacher Education from the Perspectives of Community-Based Teacher Educators. Journal of Teacher Education, 69(2), 140-153. https://doi.org/10.1177/002248711775113 3

Thompson Rivers University (2018a) Factbook $2017-$ 2018. Retrieved from https://www.tru.ca/ipe/factbooks.html

Thompson Rivers University (2018b) K-16 Research and Development Network. Retrieved from https://www.tru.ca/edsw/research/k-16research-development-network.html

Thompson Rivers University (2018c). Our Mission.

Retrieved from https://www.tru.ca/about/tru-missionstatement.html

Harris, A. (2014). Distributed leadership matters: Perspectives, practicalities, and potential Thousand Oaks, CA: Corwin Press. https://doi.org/10.4135/9781483332574

Johnston, B. (2010). The first year at university - Teaching students in transition, New York: Society for Research into Higher Education and Open University Press.

Jones, M., Hobbs, L., Kenny, J., Campbell, C., Chittleborough, G., Gilbert, A., Herbert, S., \& Redman, C. (2016). Successful universityschool partnerships: An interpretive framework to inform partnership practice. Teaching and Teacher Education, 60, 108-120. https://doi.org/10.1016/j.tate.2016.08.006

Kuh, G. D. (2008). High-impact educational practices: What they are, who has access to them, and why they matter. Washington, DC: Association of American Colleges and Universities.

Lave, S., \& Wenger, E. (1991). Situated learning: Legitimate peripheral participation. Cambridge, UK: Cambridge University Press.

Lizzio, A., \& Wilson, K. (2013). Early intervention to support the academic recovery of first-year students at risk of non-continuation. Innovations in Education and Teaching International, $\quad 50(2), \quad 109-120$. https://doi.org/10.1080/14703297.2012.76 0867

Martin, S. D., Snow, J. L., \& Franklin Torrez, C. A. (2011). Navigating the Terrain of Third Space: Tensions With/In Relationships in School-University Partnerships. Journal of Teacher Education, 62(3), 299-311. https://doi.org/10.1177/002248711039609 6

McDonald, J., Kenny, N., Kustra, E., Dawson, D., Iqbal, I., Borin, P., \& Chan, J. (2016). Educational Development Guide Series: No. 1. The 
Educational Developer's Portfolio. Ottawa, Canada: Educational Developers Caucus.

McLaughlin, C., \& Black-Hawkins, K. (2007). School-university partnerships for educational research-distinctions, dilemmas and challenges. Curriculum Journal, 18(3), 327-341. https://doi.org/10.1080/095851707015899 67

OECD (2008). Education at a glance: OECD indicators 2008. Paris: OECD.

Parkin, A., \& Baldwin, N. (2009). Persistence in postsecondary education in Canada: The latest research. Millennium Research Note \#8. Montreal, PQ: Canada Millennium Scholarship Foundation.

Pascarella, E., \& Terenzini, P. (1991). How college affects students. San Francisco: Jossey-Bass.

Peel, H. A., Peel, B. B., \& Baker, M. E. (2002). School/university partnerships: a viable model. International Journal of Educational Management, 16(7), 319-325. https://doi.org/10.1108/095135402104480 77

Potter, A., \& Bye, L.-A. (2014). "It might have worked for you but..." Evaluating the efficacy of a first year support strategy in multiple units and disciplines. The International Journal of the First Year in Higher Education, $5(2)$. https://doi.org/10.5204/intjfyhe.v5i2.232

Rayle, A. D., \& Chung, K. (2007). Revisiting firstyear college students' mattering: Social support, academic stress, and the mattering experience. Journal of College Student Retention: Research, Theory \& Practice, 9(1), 21-37.

Rodriguez, N. J. N., DiSanto, J. M., Varelas, A., Sarah Brennan, M., Wolfe, K. S., \& Ialongo, E. (2017). Building Understanding of High School Students' Transition to College. International Journal of Teaching and Learning in Higher Education, 29(2), 402-411.

Swail, S., Redd, K., \& Perna, L. (2003). Retaining minority students in higher education: A framework. for success (ASHE-ERIC Higher Education Report No. 2). San Francisco: Jossey-Bass.

Statistics Canada (2018). Table 37-10-0011-01: Postsecondary enrolments, by program type, credential type, Classification of Instructional Programs, Primary Grouping (CIP_PG), registration status and sex. Ottawa, ON: Statistics Canada. Retrieved from https://www150.statcan.gc.ca/t1/tbl1/en/ tv.action?pid $=3710001101$

Statistics Canada (2017) -----, CY [Census subdivision], British Columbia and British Columbia [Province] (table). Census Profile. 2016 Census. Statistics Canada Catalogue no. -----------. Ottawa. Released November 29, 2017.

Taylor, J. L. (2015). Accelerating Pathways to College: The (In)Equitable Effects of Community College Dual Credit. Community College Review, 43(4), 355-379. https://doi.org/10.1177/009155211559488 0

Tinto, V. (1993). Leaving College: Retbinking the Causes and Cures of Student Attrition, 2nd ed., University of Chicago Press, Chicago, IL.

Walsh, M. E., \& Backe, S. (2013). School-University Partnerships: Reflections and Opportunities. Peabody Journal of Education, 88(5), 594-607. https://doi.org/10.1080/0161956X.2013.8 35158

Wilson, K. L., Murphy, K. A., Pearson, A. G., Wallace, B. M., Reher, V. G., \& Buys, N. (2016). Understanding the early transition needs of diverse commencing university students in a health faculty: informing effective intervention practices. Studies in Higher Education, 41(6), 1023-1040. https://doi.org/10.1080/03075079.2014.96 6070

York-Barr, J., \& Duke, K. (2004). What Do We Know About Teacher Leadership? Findings From Two Decades of Scholarship. Review of Educational Research, 74(3), 255-316. https://doi.org/10.3102/003465430740032 55 


\section{Biographies}

Dr. Catharine Dishke Hondzel is the Director of the Centre for Excellence in Learning and Teaching at Thompson Rivers University. Her research projects have examined the role of teaching, culture, and the environment in fostering creativity, retention and completion in trade apprenticeships, and faculty and student perceptions of teaching at research-intensive universities.

Dr. John Churchley is the Coordinator, Teaching and Learning, in the Centre for Excellence in Learning and Teaching at Thompson Rivers University. His teaching areas are teaching and learning, music education, and leadership and management in the K12 sector. His research interests are related to aesthetic education, creativity and innovation in learning, learning through integrated arts, and leadership education.

Dr. Susan Lidster is the Project Coordinator for the K-16 Mind the Gap Program within the Centre for Excellence in Learning and Teaching at Thompson Rivers University. She is an associate professor in the School of Education with teaching responsibilities in the Bachelor and Masters of Education programs. 